\title{
PTARMIGAN AS ENGINEERS OF CHANGE IN ARCTIC ECOSYSTEMS
}

\author{
Katie S. Christie ${ }^{1}$, Mark S. Lindberg ${ }^{1}$, Roger W. Ruess ${ }^{1}$, \\ Christa Mulder ${ }^{1}$, And Joel A. SChmutz ${ }^{2}$ \\ ${ }^{I}$ The Institute of Arctic Biology, University of Alaska Fairbanks, \\ 902 N. Koyukuk Drive, Fairbanks, AK 99775, USA. \\ ${ }^{2}$ Alaska Science Center, US Geological Survey, \\ 4210 University Drive, Anchorage, AK 99508, USA.
}

EXTENDED ABSTRACT.-The rapid expansion of woody shrubs over the past half century is one of the most dramatic changes that has occurred in Alaska's arctic tundra (Myneni et al. 1997, Sturm et al. 2001, Tape et al. 2006). Shrubs have the capacity to respond quickly to a warming climate (Chapin et al. 1995, Walker et al. 2006), but a process that is likely to strongly interact with this is herbivory. Recent studies have shown that herbivory in tundra ecosystems significantly alters the response of plant communities to warming temperatures by reducing the biomass of species that would otherwise become dominant under warmer conditions (Post and Pedersen 2008, Olofsson et al. 2009). In arctic tundra ecosystems of Alaska, the primary shrub browsers are Moose (Alces alces), Arctic Hares (Lepus arcticus), and ptarmigan (Lagopus lagopus, L. muta). In the spring, ptarmigan migrate from wintering areas south of the Brooks Range to the foothills and Arctic Coastal Plain, where they form large aggregations in areas dominated by tall shrubs. The presence of these large flocks on the landscape, combined with their exclusive preference for willow buds is likely to result in a substantial influence on the growth and architecture of willows that exceed snow level. In Finland, browsing by ptarmigan significantly reduced the number of vegetative buds and catkins on willows (Hakkarainen et al. 2007). In northern Alaska $42 \%$ of buds of tall willows had been browsed by ptarmigan, resulting in widespread "hedging" where browsed willows had strongly altered height and architecture compared with un-browsed plants (Tape et al. 2010). Furthermore, selective browsing of willows may indirectly enhance the growth of other less palatable, competing shrubs such as Green Alder (Alnus viridis). Thus climate change may cause unfettered expansion of some species (e.g., alder) while other species (e.g., willow) are kept in check by herbivory.

While ptarmigan have a marked impact on shrub structure and productivity, they may also benefit from the recent shrub expansion due to increased food and cover from predators. Increased temperatures and a longer growing season in the Arctic result in increased photosynthetic activity and growth of willows and other shrubs (Myneni et al. 1997, Forbes et al. 2010). The increased cover of tall shrubs on the arctic landscape may benefit ptarmigan during the winter and spring, times when shrub habitat is limited due to snow. Information on ptarmigan distribution relative to shrub height and cover will therefore be necessary to determine how ptarmigan might respond to increasing shrub cover in the future. In addition, this information will indicate the geographic scope of the effect of their browsing in the Arctic. 
The objectives of this study are to examine patterns of spring ptarmigan distribution across the arctic landscape with respect to snow and shrub cover, and to understand the degree to which ptarmigan and other browsers influence bud population dynamics, growth, and architecture of tall riparian willows.

Aerial surveys will be conducted in April-June 2012 to estimate ptarmigan occupancy across a mosaic of different habitat types including thick patches of tall willows and upland tundra regions with shorter, more dispersed shrubs. Transects will be located in randomly selected grid cells in the foothills of the Brooks Range and on the Arctic Coastal Plain. We will use the double-observer method, allowing for unbiased occupancy estimates that incorporate detection probabilities. Observers will record the approximate number of ptarmigan in predefined grid cells, as well as shrub cover and height class. Surveys will be conducted over a two month period to assess the timing of spring ptarmigan migration to the North Slope of Alaska. Comparisons across years with varying snow conditions will indicate how snow cover influences ptarmigan distribution.

Ground-based shrub surveys will indicate the extent of browsing and subsequent growth and architectural responses of tall riparian willows to herbivory by ptarmigan, moose, and hares in the arctic. In June 2012, previously marked willows ( $S$. alaxensis) in northeastern Alaska will be re-visited to quantify browsing, architecture, and bud demography. Buds and vegetative shoots on these plants were mapped in spring 2011, and their fates will be determined after a one-year period. Ultimately, we intend to use matrix population models to compare bud population growth rates among shrubs exposed to varying levels of browsing by ptarmigan and moose. Received 11 March 2011, accepted 16 May 2011.

Christie, K. S., M. S. Lindberg, R. W. Ruess, C. Mulder, And J. A. Schmutz. 2011. Ptarmigan as engineers of change in Arctic ecosystems. Extended abstract in R. T. Watson, T. J. Cade, M. Fuller, G. Hunt, and E. Potapov (Eds.). Gyrfalcons and Ptarmigan in a Changing World. The Peregrine Fund, Boise, Idaho, USA. http://dx.doi.org/10.4080/gpcw.2011.0119

Key words: Alaska, Arctic vegetation, climate change, herbivory, ptarmigan. 


\section{Literature Cited}

Chapin, F. S., III, G. R. Shaver, A. E. Giblin, K. J. Nadelhoffer, And J. A. Laundre. 1995. Responses of arctic tundra to experimental and observed changes in climate. Ecology 73:694-711.

Forbes, B. C., M. M. FAuria, AND P. ZetterBERG. 2010. Russian Arctic warming and 'greening' are closely tracked by tundra shrub willows. Global Change Biology 16:1542-1554.

HAKKaRAinen, H., R. VirTANEN, J.O. HONKANEN, AND H. RoININEN. 2007. Willow bud and shoot foraging by ptarmigan in relation to snow level in NW Finnish Lapland. Polar Biology 30:619-624.

Myneni, S.J., C.D. Keeling, C.J. Tucker, G. ASRAR, AND R.R. NEMANI. 1997. Increased plant growth in the northern high latitudes from 1981 to 1991. Nature 38:698-702.

Olofsson,J., L. OKSAnen, T. Callaghan, P.E. HulMeK, T. OKSANEN, AND O. SuOMINEN. 2009. Herbivores inhibit climate-driven shrub expansion on the tundra. Global Change Biology 15:2681-2693.

Post, E., And C. Pedersen. 2008. Opposing plant community responses to warming with and without herbivores. PNAS 105:12353-12358.
Schickoff, U., M. D. Walker, And D. A. WALKER. 2002. Riparian willow communities on the Arctic Slope of Alaska and their environmental relationships: A classification and ordination analysis. Phytocoenologia 32:145-204.

Sturm, M., C. Racine, And K. TAPe. 2001. Increasing shrub abundance in the Arctic. Nature 411:546-547.

Tape, K., Sturm, M., and C. Racine. 2006. The evidence for shrub expansion in Northern Alaska and the Pan-Arctic. Global Change Biology 12:686-702.

TAPE, K. D., R. LORD, H. P. MARShall, AND R. W. RUESS. 2010. Snow-mediated ptarmigan browsing and shrub expansion in arctic Alaska. Ecoscience 17:96-193.

Walker, M. D., C. H. Wahren, R. D. HollisTER, G. H. R. HENRY, L. E. Ahlquist, J. M. Alatalo, M. S. Bret-Harte, M. P. Calef, T. V. Callaghan, A. B. Carroll, H. E. EPSTEIN, I. S. JónsdótTiR, J. A. Klein, B. Magnússon, U. Molau, S. F. Oberbauer, S. P. Rewa, C. H. Robinson, G. R. ShaVer, K. N. Suding, C. C. Thompson, A. Tolvanen, Ǿ. Totland, P. L. Turner, C. E. Tweedie, P. J. Webber, AND P. A. WoOKey. 2006. Plant community responses to experimental warming across the tundra biome. Proceedings of the National Academy of Science 103:1342-1346. 